\title{
VERdOORN's LAW AND PRODUCTIVITY DYNAMICS: AN EMPIRICAL INVESTIGATION INTO THE DEMAND AND SUPPLY APPROACHES
}

\author{
Guilherme R. Magacho \\ Department of Land Economy, University of Cambridge. \\ E-mail: guilherme.magacho@gmail.com
}

\section{John S. L. McCombie}

Fellow in Economics, Downing College and Director of the Cambridge Centre for Economic and Public Policy, Department of Land Economy, University of Cambridge.

E-mail: jslm2@cam.ac.uk 


\title{
Verdoorn's LAW AND Productivity DyNAMICS: AN EMPIRICAL INVESTIGATION INTO THE DEMAND AND SUPPLY APPROACHES
}

\author{
Guilherme R. Magacho and John S. L. McCombie
}

\begin{abstract}
According to Verdoorn's law, productivity growth is endogenous to output growth, due to the existence of increasing returns to scale, broadly defined. Such an idea is at the root of both the endogenous growth theory and the Kaldorian approach. Whilst in Kaldor's view, a country's growth is demand-driven, in the endogenous growth theory, growth is determined by the growth of the factors of production and hence growth is supply-constrained. This paper empirically tests both assumptions for Verdoorn's law by using a dynamic panel of manufacturing industries for 70 countries at different stages of development for the years between 1963 and 2009. In order to distinguish between these approaches, two different specifications are estimated where the growth of output and of the supply of factors of production are instrumentalised by System GMM estimators. The results show that, if it is assumed that the growth rates of countries are demanddriven, a faster growth of output increases productivity growth due to the existence of increasing returns. Alternatively, if it is assumed that output growth is driven by the growth of the supply of the factors of production, it is not possible to conclude that productivity growth is induced by output growth.
\end{abstract}

Keywords: Verdoorn's law, productivity growth, demand-led growth, increasing returns, manufacturing.

JEL Classifications: E12, O33, O47 


\section{Introduction}

One of the main explanations for differences in countries' productivity growth rates arises from the existence of static and dynamic increasing returns to scale. The centrality of this explanation is at the root of both the new growth theory and the Kaldorian approach to economic growth. New growth models arose from the criticism that the neoclassical Solow-Swan approach (Solow, 1956; Swan, 1956), assumed that steady-state productivity growth is determined by the exogenously determined rate of technical progress. The new growth theory shows that although firms may be subject to constant returns to scale, regions and countries exhibit increasing returns due to externalities generated by capital accumulation (Romer, 1986) or by resource allocation in specific activities, such as R\&D and education (Lucas, 1988; Romer, 1990). This has shifted the focus of the neoclassical models from exogenous technological change to the externalities generated by the growth process itself.

These models, however, have paid little attention to sectoral specificities in explaining differences in countries' growth rates, as well as neglecting the importance of the growth of demand. Although these models emphasise the importance of some activities, such as R\&D, increasing returns are not associated with the size of any specific sector, such as manufacturing, agriculture or services (Palma, 2005). Furthermore, productivity growth is ultimately constrained by the growth of the supply side and, in these models, the latter is determined exogenously, rather than induced by the growth of demand (McCombie, 2002; Dutt, 2006).

In contrast to the new growth theory, the Kaldorian approach stresses the existence of increasing returns to scale in some sectors and the importance of demand as an ultimate source of growth. Unlike the endogenous growth theories, Kaldor $(1966 ; 1972)$ emphasised that sectors have different degrees of increasing returns, and thus countries may grow at different rates due to differences in their sectoral structure of production. Moreover, capital is a produced means of production and investment responds to demand. Consequently, output growth determines the rate of capital accumulation, and technological change is, to a large extent, induced by the growth of demand.

Therefore, although both the new growth theory and the Kaldorian approach consider that productivity growth is partly determined by output growth, in the former approach, output growth is constrained by the supply of factors of production, while in the latter, it is determined by the growth of demand. This distinction is significant empirically because different results concerning the existence of increasing returns to scale can be obtained according to which assumption is adopted in specifying the regression model. 
This paper applies a panel data analysis for 70 countries where instrumental variables are used both for the demand-oriented and supply-oriented approaches in order to test both approaches empirically. The aim of this analysis is to determine to what extent the assumptions about the ultimate determinants of output growth are important in understanding the dynamics of productivity growth.

The paper is divided into five sections, in addition to this introduction. In the next section, the debate over the different specifications of Verdoorn's law is presented, focusing on the implications of the demand-oriented and supply-oriented approaches for the existence of increasing returns to scale. Section 3 presents a method to estimate Verdoorn's law from the demand-side and supply-side and approaches, contrasting their assumptions. Section 4 discusses the data used in the estimations, as well as the sectoral aggregation and the estimation method used. In Section 5, Verdoorn's law is estimated based on each approach by using a large database for countries in different stages of development in order to contrast the results. Finally, the last section presents the concluding remarks.

\section{Verdoorn's law specifications and interpretations}

Based on countries' data for two lengthy periods (between 1870-1914 and 1914-1930), Verdoorn (1949) established a long-term relationship between industrial productivity growth and output growth, by estimating the following equation:

$$
q=\lambda+b y \quad(1)
$$

where $q$ is industrial productivity growth, $y$ is industrial output growth, $\lambda$ is the rate of technical progress not explained by output growth and $b$ is the elasticity of productivity with respect to output growth, known as the Verdoorn coefficient.

Verdoorn (1949) found an average value of "approximately 0.45 (with limits of 0.41 and 0.57)" for the elasticity of productivity growth with respect to output growth. Verdoorn (1949, Appendix) derived the relationship from a Cobb-Douglas production function, initially expressed in levels. He suggested that one could have expected these results a priori because the division of labour depends upon the volume of production, which, in turn, creates scope for rationalisation and increased mechanisation.

Kaldor (1966) argued for a one-way causal relationship between these two variables. $\mathrm{He}$ stressed that Verdoorn's findings reflect a dynamic, rather than a static, relationship which is 
between productivity and output growth, primarily because technological progress enters into it. According to Kaldor, a faster growth rate of output induces faster productivity growth due to the existence of dynamic increasing returns to scale in manufacturing and induced technical change. ${ }^{1}$

In a series of papers, Rowthorn (1975a; 1975b) and Kaldor (1975) debated the most appropriate specification of the law based on both theoretical and empirical issues. According to Rowthorn (1975a), the law should be estimated explicitly as the elasticity of productivity growth with respect to employment growth, as output growth is constrained by the growth of the labour force. This was what Kaldor (1966) initially assumed was the case for the UK in the early postwar period, although he later changed his mind (Kaldor 1975). Hence, according to Rowthorn, in contrast to equation (1), the law should be estimated as follows:

$$
q=\frac{\lambda}{1-b}+d l
$$

where $l$ is employment growth and $d=b /(1-b)$ is the elasticity of productivity with respect to employment. By doing so, Rowthorn, using data for the advanced countries, found that there is a positive Verdoorn coefficient, but it depends solely on the inclusion of Japan in the analysis. ${ }^{2}$

Kaldor (1975) replied that Rowthorn's estimation procedure is correct only if one considers that the growth rates of factors of production are exogenously determined. However, output growth, rather than that of labour or capital, is the exogenous variable. According to Kaldor, capital required for industrial production is self-generated by output growth as investment responds to the growth of demand. Labour is absorbed by manufacturing during the process of industrialisation because it has a low opportunity cost of employment in agriculture and services. Moreover, additional labour can be obtained from disguised unemployment and immigration. In this sense, Kaldor argued that the original specification, given by equation (1), was the more appropriate way to estimate Verdoorn's law. ${ }^{3}$

The main conclusions of this debate are twofold. First, the results of the estimations for the degree of increasing returns to scale depend on the variables that are considered as exogenous. On the one hand, the demand-side specification assumes that the growth of output is exogenous, which implies that causation runs from growth of demand to productivity growth. One the other hand, the supply-side specification assumes that the growth of the supply of factors of production is exogenous and thus, the causation runs in the other direction.

Secondly, because output, employment and productivity are conjunctly determined, Verdoorn's should be estimated using an instrumental variables approach to guard against 
simultaneous equation bias. Both Kaldor's and Rowthorn's specifications rely on the assumption that the explanatory variable is exogenously determined. However, due to the notion of cumulative causation, productivity growth is endogenous to output growth (Verdoorn's law). But output growth is, in turn, determined by productivity growth, if the latter affects the price competitiveness of countries, or regions, and thus their exports. Hence, the need for an instrumental variable technique to estimate the law correctly (Rowthorn, 1975b). ${ }^{4}$

According to Angeriz et al. (2008), the distinction between the supply-side and demandside specifications is important, because estimating Verdoorn's law by the different approaches produces different results. Moreover, it is necessary to consider these different views because they depend on a priori theoretical arguments. On the one hand, the neoclassical endogenous growth approach assumes that savings determine investment, and, consequently, the estimations produced by the supply-side specification are more appropriate to estimate the degree of increasing returns. On the other hand, the Kaldorian approach sees investment as being determined by the accelerator mechanism and profits, rather than by savings and, consequently, the demand-side specification is the more appropriate.

Based on this distinction between supply-side and demand-side specifications, some studies have attempted to estimate Verdoorn's law using both these two approaches. McCombie and de Ridder (1984), for example, constructed a series for the capital stock with the aim of controlling for the growth of the non-labour inputs, and estimated the law for total manufacturing for 49 US states. Their results show that both specifications corroborate the presence of increasing returns to scale in manufacturing, even though it is greater if the demand-side specification is used. While the supply-side specification gives a value of returns to scale of 1.33, Kaldor's specification gives a value of 1.45. Consequently, the results for both specifications were in line with the traditional approach, providing further evidence for the existence of increasing returns to scale in manufacturing.

More recently, Angeriz et al. (2008) estimated the law based on both the supply-side and demand-side specifications for EU regional data, controlling for spatial autocorrelation and using an instrumental variable (IV) approach. They found values for the degree of returns to scale that were statistically significantly greater the unity when output growth is the regressor. However, in contrast to the results obtained by McCombie and de Ridder (1984), they found that when the growth of factor inputs are specified as the regressors, the estimates suggested that manufacturing industries are subject to either diminishing, or constant returns, to scale. These results highlighted the importance of distinguishing between the supply and demand approaches, even when an IV procedure is used. 


\section{Methods and data}

\subsection{Estimating Verdoorn's law: demand- and supply-side specifications}

Section 2 discussed the problems of estimating the long-term relationship between the growth of productivity and output through equation (1), as Verdoorn (1949) and Kaldor (1966) did, and the growth of productivity and employment using equation (2), as suggested by Rowthorn (1975a). Furthermore, although Verdoorn's law addresses the importance of technological change in promoting growth, if we assume that investment is induced by the growth of output, the latter has two impacts on productivity growth. First, an increase of output increases the capital-labour ratio, which has a direct impact on productivity due to the increase of "the same kind" of capital in the production process. Secondly, increased output stimulates investment in new technologies and thus labour productivity increases through induced technological change, which is part of Kaldor's explanation for Verdoorn's law. In this sense, to estimate Verdoorn's law from a Kaldorian perspective, it is necessary to include the growth of the capital stock. ${ }^{5}$

Hence, the regressions discussed in Section 2 are unable to estimate correctly the degree of increasing returns, unless an assumption is made about the growth of the capital stock. A more appropriate specification must consider explicitly the direct impact of the growth of the capital stock and the effect of technological change induced by the growth of output, and hence investment, through, say, a technical progress function.

It is now well established that aggregate production functions are merely picking up an accounting identity, and the data will suggest constant returns to scale regardless of the actual degree of increasing returns (Felipe and McCombie, 2013). However, Verdoorn's law can still be interpreted as showing increasing returns to scale, although not within the conventional framework. According to McCombie and Spreafico (2016), as theoretically an aggregate production function does not exist, one cannot interpret the intercept as the separate contribution of exogenous technological change to growth. In addition, the Verdoorn coefficient should not be interpreted as a measure of increasing returns to scale, per se. All that can be said is that a faster growth of output leads to a faster growth of productivity due to many factors, such as induced technological change, increasing returns and greater efficiency in the use of resources, but one cannot determine their individual contributions to productivity growth. Hence, if the coefficients are not interpreted as the contributions of the various factors that determine growth, such as in the 
neoclassical approach, Verdoorn's law can still be estimated based on this approach. However, here we follow the traditional approach. ${ }^{6}$

Following McCombie (2002), it is assumed that output growth is determined by the growth of capital, labour and technical progress, as follows:

$$
y_{i}=\lambda+\alpha l_{i}+\gamma k_{i}
$$

where $\lambda$ is the rate of technical progress, $y, k$, and $l$ are the growth rates of output, capital and labour of firm, or industry, $i . \alpha$ and $\gamma$ are the output elasticities of labour and capital, where $\alpha+$ $\gamma=\varphi$ measures the degree of internal returns to scale, and $\alpha=\varphi a$ and $\gamma=\varphi(1-a)$.

According to the Kaldorian view of Verdoorn's law, the rate of technical progress is partially determined by the growth of output. Hence, the rate of technical progress at the industry, or manufacturing, level is given by:

$$
\lambda=\bar{\lambda}+\pi y
$$

where $\bar{\lambda}$ is the rate of exogenous technical progress, and $\pi$ is the elasticity of induced technical progress in respect to the growth of output, where it is assumed that $0 \leq \pi<1$ (The $i$ subscript is dropped for notational convenience.) Although many authors have emphasised the existence of induced technical progress in different forms, such as Arrow (1962), who stressed the importance of learning-by-doing at the firm level, and Young (1928), who focused on increasing returns on the macroeconomic level, here induced technical progress is also due to the existence of localisation economies, once production is considered at the industrial level. ${ }^{7}$

Substituting (4) into equation (3) and using the conditions that $\alpha=\varphi a$ and $\gamma=\varphi(1-a)$, we obtain:

$$
y=v\left[\lambda^{\prime}+a l+(1-a) k\right]
$$

where $v=\varphi /(1-\pi)$ is the degree of encompassing increasing returns and $\lambda^{\prime}=\bar{\lambda} / \varphi$. In this equation, the importance of factor accumulation for economic growth is made explicit. In contrast to equations (2) and (3), where one can only see implicitly the direct impact of the growth of both of the factors of production on output growth, here it is possible to see that accumulation of capital 
and the growth of labour increases output growth by stimulating endogenous technical progress. This will occur if the degree of encompassing increasing returns, $v$, is greater than the unity.

Re-arranging equation (5), it is possible to present Verdoorn's law, augmented by capital accumulation, as follows:

$$
q=\frac{\lambda^{\prime}}{a}+\frac{v a-1}{v a} y+\frac{(1-a)}{a} k
$$

According to the demand-led approach for Verdoorn's law, capital accumulation is not determined exogenously by savings. Instead, it is induced by demand growth. Hence, equation (6) can be rearranged to present a production function where the impact of the change in the capitaloutput ratio on productivity is made explicit:

$$
q=\frac{\lambda^{\prime}}{a}+\frac{v-1}{v a} y+\frac{1-a}{a}(k-y)
$$

In this equation, productivity growth is explained by the impact of exogenous technological change, output growth and the rate of increase of the capital-output ratio. The Verdoorn coefficient can be obtained directly from this equation by assuming ex-ante that capital and output grow at the same rate in the long run, which is one of Kaldor 's (1961) stylized facts. In so doing, equation (7) is equal to equation (1), which is the original Verdoorn's law. Alternatively, the rate of growth of the capital-output ratio can be included directly in Verdoorn's law. In the approach here, the law is specified as allowing for changes in the capital-output ratio. The Verdoorn coefficient, which is the long-term impact of output growth on productivity growth, can be expressed as:

$$
b=\frac{v-1}{v a} \quad(8) .^{8}
$$

It can be seen that a positive value for the Verdoorn coefficient implies the presence of increasing returns to scale.

This methodology is important because it considers explicitly that output growth is exogenous to the growth of productivity, and thus it implies that demand factors are the main drivers of the growth process. 
Another possibility for estimating the degree of increasing returns is by re-arranging equation (5) to consider explicitly the impact of the growth of the factors of production on that of labour productivity, as follows:

$$
q=v \lambda^{\prime}+(v a-1) l+v(1-a) k \quad(9)
$$

As with equation (7), in equation (9) the direct and indirect impacts of capital accumulation on productivity growth are made explicit. Essentially, both approaches consider that if capital embodies technological advances and generates external economies, we can explain at least part of technological change by capital accumulation (if $v$ is greater than the unity). The difference between equations (7) and (9) is that in equation (9) the growth rates of the factors of production (inputs) are taken to be regressors, so it is the supply-side specification of Verdoorn's law (i.e., Rowthorn's version including the growth of capital as well as labour), whilst in equation (7) output growth is a regressor.

\subsection{The human capital augmented specification}

Because Verdoorn's law is estimated in this paper for countries at different stages of development, it is important to consider that educational levels differ significantly across countries, and that labour is not homogenous. Mankiw et al. (1992), for example, show that Solow's model augmented with human capital can explain more precisely countries' growth paths during the post-war period. In this view, the growth of labour in a production function must be adjusted for the degree of schooling in order to account for the growth of human capital. In an alternative approach, Amable (1993) argues that a higher level of schooling enhances the rate of technical progress. According to him, the technical skills of the labour force is essential for both borrowing external technologies and for developing technology indigenously. Hence, the level of education (not simply its growth rate) increases the pace of technological progress.

Therefore, in order to consider that the quality of labour differs between countries, the specification needs to account for each country's level of schooling. Assuming technological change as determined, as before, by an exogenous component, $\bar{\lambda}$, and endogenously by output growth, as before, but also by human capital, equation (4) is replaced by:

$$
\lambda=\bar{\lambda}+\pi y+\rho H \quad(10)
$$


where $H$ is the level of schooling, and $\rho$ measures the impact of schooling on technological change. Therefore, if one assumes the educational level to be exogenous, output growth will be given by equation (11), instead of (5):

$$
y=v\left[\lambda^{\prime}+a l+(1-a) k+\rho^{\prime} H\right]
$$

where $\rho^{\prime}=\rho / \varphi$. Thus, we can proceed exactly as before, but instead of estimating equations (7) or (9), we estimate equation (12), for the demand-side version and equation (13) for the supplyside version of Verdoorn's law, as follows:

$$
q=\frac{\lambda^{\prime}}{a}+\frac{v-1}{v a} y+\frac{1-a}{a}(k-y)+\frac{\rho \prime}{a} H
$$

and

$$
q=\lambda^{\prime}+(v a-1) l+v(1-a) k+\rho^{\prime} H
$$

\subsection{Increasing returns to scale and the technological gap}

The estimation of Verdoorn's law also needs to consider that the technological gap may affect productivity growth. The fact that countries at a lower technological level than countries at the innovation frontier have the possibility of imitating, and thus growing faster, has been discussed in the context of both approaches.

In the neoclassical approach, the idea that the technological gap is a relevant explanation for productivity growth is presented, for example, by Barro and Sala-i-Martin (1997). They argue that although there are costs of imitation, if they are lower than the costs of invention, the technological gap is relevant in explaining productivity convergence. According to Rodrick (2013), manufacturing is the sector for which imitation is the easiest, and thus specialising in manufacturing is an important method of catching-up.

Cornwall and Cornwall (2002) also argue that in the literature on catching-up, the prime determinant of growth is the size of the technology gap, with the less advanced economies growing faster. From a Kaldorian perspective, they argue that investment embodies the most advanced technologies and thus for two countries with the same investment rate, the less developed is the economy, the higher is the growth bonus. 
The importance of the technological gap in explaining productivity growth is also addressed from a neo-Schumpeterian perspective. According to Fagerberg (1994) and Fagerberg and Verspagen (2002), the Solow neoclassical growth model assumes that technology is a public good, and thus countries' productivity differences cannot be explained by the technological gap. However, technology, rather than being a global public good, is embodied in organisational structures, such as firms and regions. Hence, engaging in technological catch-up (narrowing the technology gap) is an important source of productivity growth.

Therefore, the technological gap must be taken into account to estimate correctly Verdoorn's law, and thus the growth rate of an individual industry, rather than given by equation (11), is given by:

$$
y=v\left[\lambda^{\prime}+a l+(1-a) k+\rho^{\prime} H+\theta^{\prime} G\right]
$$

where $G$ is the technological gap, and $\theta^{\prime}=\theta / \varphi$ measures the impact of the technological gap on output (and hence productivity) growth.

Based on this, equation (12) can be re-specified as equation (15), which is the demand-side version of Verdoorn's law, augmented for human capital and the technological gap. Equation (13) can be re-specified as equation (16), which is its supply-side version:

$$
q=\frac{\lambda^{\prime}}{a}+\frac{v-1}{v a} y+\frac{1-a}{a}(k-y)+\frac{\rho \prime}{a} H+\frac{\theta \prime}{a} G
$$

and

$$
q=\lambda^{\prime}+(v a-1) l+v(1-a) k+\rho^{\prime} H+\theta^{\prime} G
$$

\section{Data, sectoral aggregation and method}

\subsection{Data and sectoral aggregation}

Verdoorn's law is estimated using a panel dataset for 70 countries between 1963 and 2009. Data for employees and value added are available in the UNIDO Industrial Statistics Database at the 2-digit level of the International Standard Industrial Classification (ISIC), Rev. 3 (UNIDOINDUSTAT2). Data for output and value added, however, are only available in nominal prices (US current prices or the various national currencies), and it is therefore necessary to deflate them 
before conducting the econometric tests. Although countries' price indices by sector should be used to deflate the output data, these indices are not available for most of the analysed countries. Therefore, in the absence of the ideal deflator, it is replaced with the GDP deflator for each country. These deflators are available in the Penn World Table (PWT) 7.1 (Helson et al., 2012).

Another relevant issue is that data on fixed capital stocks are not available. This variable is therefore calculated using data for gross fixed capital formation (GFCF), also available in the UNIDO database, across countries and sectors at the ISIC 2-digit level. Following the approach adopted in Angeriz et al. (2008), GFCF data is combined with approximations of probable average asset lives to calculate the gross fixed capital stocks. Investment deflators, also available at PWT 7.1 , for each country are applied to deflate this data.

The main issue with these data, however, is that they are not available for all countries in the same years and do not employ a common sectoral division. Therefore, before performing the regressions, each country was analysed separately with the aim of identifying those countries that were to be used and those that were to be discarded, as well as the level of sectoral aggregation that minimises the missing values. Although data on employees, output or value added and gross fixed capital formation are available between 1963 and 2009 for 38 countries, most of these are developed countries, and may lead to sample bias. As a result, data on other countries have to be analysed (and in some cases calculated by interpolation) prior to conducting the econometric tests.

In terms of the sectoral aggregation, sectors originally classified at a 2-digit level of the International Standard Industrial Classification (ISIC) are grouped to make it possible to extend the analysis for the longest possible time series. The sectors considered are the following: food, beverages and tobacco products [Food]; textiles, wearing apparel and leather products [Textiles]; wood and paper [Paper]; fuels [Fuels]; chemicals, rubber and plastic [Chemicals]; non-metallic mineral products [Non-metallic]; basic and fabricated metals [Metals]; machinery, equipment, office and computing machinery [Machinery]; electrical machinery, communication, medical, precision and optical equipment [Electrical]; motor vehicles and other transport equipment [Transport]; and furniture and other manufacturing products [Others].

Finally, these sectors are grouped according to their technological intensity and categories of demand. Regarding the aggregation by technological intensity, industries are grouped based on UNIDO (2013:205) classification for manufacturing activities. Food, Textiles, Paper, Fuels, Nonmetallic, Metals and Others are grouped as low-tech manufacturing industries [LT] and Chemical, Machinery, Electrical and Transport as high-tech manufacturing industries [HT]. In terms of the categories of demand, Food, Paper, Fuels, Non-metallic and Metals are grouped as natural resource based manufacturing [NR], Textiles and Others as consumption goods chains [CG] and 
Machinery, Electrical and Transport as capital goods chains [KG]. Because Chemicals cannot be considered as either capital or consumption goods, this sector is not classified in any of these groups.

The analysis also uses data for the level of schooling to estimate Verdoorn's law, as well as the technological gap. Regarding the level of schooling, $H$, data on the average years of total schooling (for the population aged 15 and over) are obtained from Barro and Lee's (2012) dataset.

The technological gap is defined as the complexity of the countries' sectoral exports in relation to the US. Following Hausmann et al. (2007), a proxy for the technological complexity of sectoral exports is obtained based on the income per capita of the countries that export similar goods. First, using the UN-COMTRADE database (SITC Rev.1), the weighted average of the income per capita of the countries that export each good is calculated, as follows:

$$
P R O D Y_{k}=\sum_{j} \frac{X_{j k} / X_{j}}{\sum_{j} X_{j k} / X_{j}} G D P p c_{j}
$$

where GDPpc is the GDP per capita (obtained at PWT 8.0), $X$ are exports, $j$ stands for the country and $k$ stands for the product. Then, the technological complexity of exports for the sector $i$ is calculated by the weighted average of each good, PRODY, as follows:

$$
E X P Y_{j i}=\sum_{k} \frac{X_{j k}}{X_{j i}} P R O D Y_{k}
$$

where $k$ stands for all products classified inside sector $i$. Finally, for each sector $i$, the variable technological gap, $G$, is defined as the ratio between the sectoral EXPY of the country under consideration for the current year divided by the US's EXPY for the same sector in the same year.

\subsection{Estimation method}

The estimation technique employed here, as well as those employed in the other regressions in this paper, is the System GMM estimator (Brundel and Bond, 1998). This estimator was developed based on the Arellano and Bond (1991) GMM estimator (AB estimator), which considers two sources of persistence over time: autocorrelation due to the inclusion of lagged variables, and individual effects, controlling for the heterogeneity among countries. In these estimators, the orthogonality between lagged variables and the disturbances generates additional instruments. The difference between $\mathrm{AB}$ and System GMM estimators is that the latter is estimated 
without exogenous regressors. Essentially, the System GMM estimator uses lagged differences as instruments for equations in level and lagged levels as instruments for equations in first difference. Hence, there is no need to find exogenous regressors as instruments for output growth.

As Verdoorn's law is a long-run relationship between productivity and output growth, its estimation should be undertaken using average growth rates calculated over periods long enough to avoid merely picking up the short-run cyclical relationship between these two variables, which is reflected in Okun's law. The latter is the relationship between the rate of change of output and unemployment (and employment) over the business cycle. It results from the fact that cyclical changes in the observed measures of the capital stock and total hours worked do not correctly measure short-run changes in the flow of their services. Labour is a "quasi-fixed factor" (Oi, 1962). Moreover, due to data limitations, it is not possible adequately to correct for these measurement errors. Hence, the finding that there is a positive relationship between productivity growth and output growth using annual or quarterly data has nothing to do with the existence or otherwise of increasing returns to scale, but is merely reflecting the Okun effect (McCombie and de Ridder, 1983). Consequently, it is important to use growth rates calculated over time periods that are long enough to avoid these short-run pro-cyclical fluctuations in productivity growth, which will be confused with estimates of the Verdoorn coefficient. ${ }^{9}$

Therefore, to avoid this misspecification issue, rather than using annual growth rates, growth rates for seven-year periods are used, from 1967 to 1973 and 1973 to 1980, and so on. Alternatively, it would be possible to use the variables from the same data set in log-levels to analyse this relationship (rather than growth rates) using cross-country data for, say, the terminal years. However, McCombie (1982) shows that estimating the law through these two different methods gives different results. Verdoorn's law obtained using exponential growth rates (which reflects Verdoorn's original approach) gives support for the existence of increasing returns to scale, whilst estimations based on log-level values often suggest constant returns to scale. This result is known as the "static-dynamic Verdoorn's law paradox", and is found in many other studies. McCombie and Roberts (2007) argue that if Verdoorn's law is correctly specified, the paradox can be attributed to spatial aggregation bias. When data are summed by the statistical authorities to the regional level (including, for example, countries and states), the relationship between the variables is at a higher level of aggregation than the correct unit of observation. This leads to a bias towards constant returns to scale when log-levels are used. Nevertheless, McCombie and Roberts (2007) show theoretically, and by simulation analysis, that the dynamic law will give a relatively unbiased estimate of the true degree of encompassing returns to scale. Angeriz et al. (2009) provide empirical evidence in support of this hypothesis. 
Moreover, even though long-run average growth rates are used, it is still important to take into account the effect of lagged variables on the growth of productivity in the regression analysis (Setterfield, 1997).

\section{Different specifications, different results}

\subsection{The demand-side version}

As discussed in Section 3, different approaches can be adopted to estimate the relationship between productivity growth and output growth according to which variables are assumed to be the regressors. In the demand-side version, output is exogenous to the growth of the inputs (capital and labour), once demand is the ultimate determinant of output growth. Therefore, in order to determine the degree of increasing returns from this approach, based on equations (7), (12) and (15), the Verdoorn coefficient is estimated using equations (19) to (20), as follows:

$$
\begin{gathered}
q_{j}=\beta_{0}+\delta q_{j, t-1}+\beta_{1} y_{j, t}+\beta_{2} y_{j, t-1}+\beta_{3}\left(k_{j, t}-y_{j, t}\right)+\varepsilon_{j, t} \\
q_{j}=\beta_{0}+\delta q_{j, t-1}+\beta_{1} y_{j, t}+\beta_{2} y_{j, t-1}+\beta_{3}\left(k_{j, t}-y_{j, t}\right)+\beta_{4} H_{j, t}+\varepsilon_{j, t} \\
q_{j}=\beta_{0}+\delta q_{j, t-1}+\beta_{1} y_{j, t}+\beta_{2} y_{j, t-1}+\beta_{3}\left(k_{j, t}-y_{j, t}\right)+\beta_{4} G_{j, t}+\varepsilon_{j, t} \\
q_{j}=\beta_{0}+\delta q_{j, t-1}+\beta_{1} y_{j, t}+\beta_{2} y_{j, t-1}+\beta_{3}\left(k_{j, t}-y_{j, t}\right)+\beta_{4} G_{j, t}+\beta_{5} H_{j, t}+\varepsilon_{j, t}
\end{gathered}
$$

where the subscript $j$ represents each country, $\varepsilon_{j, t}$ is the error component, which includes panelspecific error terms for years and countries, and the estimate of $(v-1) / v a$ (the Verdoorn coefficient), is given by

$$
\widehat{b}_{1}=\frac{\widehat{\beta}_{1}+\widehat{\beta}_{2}}{1-\widehat{\delta}}
$$

Table 1 presents the Verdoorn coefficients estimated from equations (19) to (22) based on the System GMM estimator for individual industries, different sectoral aggregations and total manufacturing. From the results, it is clear that all but two of the industries exhibit a statistically significant Verdoorn coefficient, which indicates that they are subject to dynamic increasing 
returns to scale. Including the schooling and technological gap variables in the regressions has very little effect on the size of the estimate of the Verdoorn coefficient.

Table 1 - Estimated Verdoorn coefficient (demand-side version), by industries and level of aggregation [about here]

Manufacturing takes a value of 0.572 when both controls are included in the regression. If we assume that $a$ takes a value of 0.75 , then this implies a large value of encompassing returns to scale of 1.75. There is a range of values for the Verdoorn coefficient according the specific industries but they are all statistically significant and take a value of 0.334 or above. The exceptions are Others and Consumption Goods where the Verdoorn coefficient is not statistically significant. The industries Food, Fuels, Chemicals, Metals and Natural Resources all have values that exceed that of manufacturing.

Turning to the sectoral results, the comparison between Capital Goods and Natural Resources shows that although the value of the Verdoorn coefficient is higher in the latter, where it is over 0.6 , this difference is not statistically significant at the $10 \%$ confidence level. ${ }^{10}$ Finally, with regard to the category of technological intensity, both the High-tech and Low-tech industries have statistically significant Verdoorn coefficients 0.482 and 0.502 respectively when the controls are included in the regressions. However, the difference between these values is not statistically significant at the $10 \%$ confidence level. ${ }^{11}$

Overall, these results contradict the view of Young (1928) and, following him, Kaldor (1966), that increasing returns are largely a macroeconomic phenomenon. Kaldor, for example, argues that Verdoorn's law is not to be found at the firms or industry level, but it is derived from the inter-industry division of labour and specialisation. Consequently, the largest increasing returns to scale are to be found at the level of total manufacturing. However, the results here confirm those of other studies, such as McCombie (1985) and Angeriz et al. (2009), that have found significant Verdoorn coefficients at the level of the individual industries. ${ }^{12}$

\subsection{The supply-side version}

The assumption that the growth of factor inputs are exogenous to output growth implies that long-term economic growth is not determined by the growth of demand, as emphasised by Kaldor $(1966 ; 1970)$. Instead, it is determined by the capability of a country to increase savings by 
reducing consumption or by the allocation of resources to activities that generate substantial positive externalities, such as R\&D and education. This notion is at the root of the neoclassical endogenous growth models, in this supply-side, or supply-oriented, approach. Therefore, equations (9), (13) and (16) are estimated to obtain the degree of increasing returns.

As in the case of the estimation of the demand-side approach, it is necessary to consider that the relationship between productivity growth and output growth is a long-term relationship. Hence, the same method to calculate seven-year growth rates, rather than annual growth rates, is applied. Moreover, lags are also considered in the estimation to account for the impact of investments in former periods. The following equations are thus estimated through a System GMM:

$$
\begin{gathered}
q_{j}=\beta_{0}+\delta q_{j, t-1}+\beta_{1} l_{j, t}+\beta_{2} l_{j, t-1}+\beta_{3} k_{j, t}+\beta_{4} k_{j, t-1}+\varepsilon_{j, t} \\
q_{j}=\beta_{0}+\delta q_{j, t-1}+\beta_{1} l_{j, t}+\beta_{2} l_{j, t-1}+\beta_{3} k_{j, t}+\beta_{4} k_{j, t-1}+\beta_{5} H_{j, t}+\varepsilon_{j, t} \\
q_{j}=\beta_{0}+\delta q_{j, t-1}+\beta_{1} l_{j, t}+\beta_{2} l_{j, t-1}+\beta_{3} k_{j, t}+\beta_{4} k_{j, t-1}+\beta_{5} G_{j, t}+\varepsilon_{j, t}
\end{gathered}
$$

and

$$
q_{j}=\beta_{0}+\delta q_{j, t-1}+\beta_{1} l_{j, t}+\beta_{2} l_{j, t-1}+\beta_{3} k_{j, t}+\beta_{4} k_{j, t-1}+\beta_{5} G_{j, t}+\beta_{6} H_{j, t}+\varepsilon_{j, t}
$$

where the subscript $j$ represents each country, $\varepsilon_{j, t}$ is the error component, which includes panelspecific error terms for years and countries.

From these regressions, the estimate of the Verdoorn coefficient, $(v-1) / v a$, is given by:

$$
\widehat{b}_{2}=\frac{\widehat{\beta}_{1}+\widehat{\beta}_{2}+\widehat{\beta}_{3}+\widehat{\beta}_{4}}{(1-\widehat{\delta})\left(1+\widehat{\beta}_{1}+\widehat{\beta}_{2}\right)}
$$

Table 2 presents the results of the supply-oriented specification for the individual industries, different sectoral aggregation and total manufacturing. From these results, it is clear that industries are not subject to statistically significant increasing returns. For example, manufacturing has a value for returns to scale of 0.822 when the controls are included, but this value is not statistically significantly different from unity. (It is assumed again that $a$ equals 0.75 )

This true for all the specifications of all the individual industries and sectors. An increase in the growth of factor inputs has a statistically insignificant impact on labour productivity growth 
(at the 5\% level), even when the Verdoorn coefficient is positive, which means that the industries are either subject to constant or diminishing returns to scale. These results corroborate the findings of Angeriz et al. (2008) for total manufacturing and the findings of Angeriz et al. (2009) for individual manufacturing industries. In their studies, they show that in the demand-side specification, manufacturing and its individual industries are subject to increasing returns, whilst in the supply-side specification they are not. Here, these findings are extended and are based on countries in different stages of development, but the results remain the same.

Consequently, although an instrumental variable approach has been used to estimate both the demand-oriented and the supply-oriented approaches, the method of normalisation, i.e., variables are chosen as the regressors, still makes a significant difference to the values of the estimates. This will occur when a regression equation is over-identified using methods based on classical least squares or when different instruments are used.

Table 2 - Estimated Verdoorn coefficient (supply-side version), by industries and level of aggregation [Here]

Consequently, the comparison between the demand-side and supply-side specification results shows that the assumptions made about the determinants of investment and labour mobility are very relevant in explaining cumulative causation and disparities in the growth rates of countries. One the one hand, based on the supply-side assumption, the results suggest that productivity growth is not induced by output growth, as the estimates show that the industries are not subject to increasing returns. On the other hand, the Kaldorian view is substantiated to the extent that if one assumes growth is ultimately demand driven, productivity growth responds positively to output growth.

Therefore, only if it is assumed that growth is demand-driven rather than supply-driven, can it be inferred that technological progress is induced by output growth, and thus high and sustained growth rates depend on the specialisation in those sectors with the highest degree of increasing returns to scale, namely manufacturing and individual industries such as natural resources and capital goods.

\section{Concluding remarks}

The existence of increasing returns to scale is one of the main explanations for the divergence in countries' per capita income. According to the new growth theory (Romer, 1986, 
1990; Lucas, 1988), although firms may be faced internally with constant returns to scale, regions and countries exhibit increasing returns, due to the externalities generated by the production process. This view is shared by the Kaldorian approach, which argues that a faster growth of output can increase productivity growth, especially in manufacturing, because this sector presents dynamic increasing returns to scale.

Besides the fact that the Kaldorian view argues that dynamic increasing returns are sectorspecific, there is another important difference between the Kaldorian and the new growth theory. Although in both views productivity growth is endogenous to output growth, in the new growth theory, growth is ultimately supply determined, while, in the Kaldorian approach, growth is demand-driven.

This difference is important because the regression results concerning the existence of increasing returns to scale may vary according to which assumption is adopted. In the supply-side view, which was presented originally by Rowthorn (1975a), a faster growth of factor inputs promotes a faster growth of output, which, in turn, may increase productivity growth. In this view, factor inputs are exogenous to output growth. On the other hand, in the demand-side version of this relationship, which was presented originally by Verdoorn (1949) and Kaldor (1966), demand is exogenous to output growth even in the long run, once investment and the growth of labour services are stimulated by growth of demand. The latter occurs through the transfer of labour from low productivity (agriculture, services) to high productivity sectors (such as manufacturing), immigration, the more efficient use of the existing labour force, and the reduction of disguised unemployment.

With the aim of testing the degree of returns to scale based on both the demand-side and the supply-side approaches, a panel analysis was undertaken for 70 developed and less developed countries where instrumental variables were used for both specifications. Variables to capture the effect of human capital and the technological gap were also included.

In spite of using the instrumental variable approach, the results show that these assumptions are very important in understanding the growth process. By estimating Verdoorn's law through a Kaldorian approach, we found significant results for dynamic increasing returns to scale, whilst the results obtained through the supply-side version of the law suggest that manufacturing and its industries are not subject to increasing returns.

In this sense, if one considers a priori the Kaldorian view, in which investment and thus factor inputs are determined by the growth of demand, then manufacturing industries are subject to increasing returns to scale, which means that productivity growth in this sector is determined by demand growth. Conversely, if one assumes that factor inputs are exogenous with respect to 
demand in the long run, as in the neoclassical or endogenous growth models, then manufacturing industries are subject to constant returns to scale, and thus productivity growth is not induced by output, as predicted by Verdoorn's law. This is even when instrumental variables are used. Therefore, a priori assumptions about the determinants of output growth are still relevant in explaining the relationship between productivity and output growth. Once it is assumed that output growth (and hence factor inputs) are endogenously determined by demand growth, then manufacturing industries present significant degrees of increasing returns, and thus productivity growth is demand-driven due to the existence of dynamic increasing returns to scale, and it is strictly related to specialization in manufacturing.

\section{Notes}

1. Some authors consider that this relationship could result if increases in productivity growth reduce the growth of relative prices, which in turn might increase the growth rate of demand for particular industries (Salter, 1966). Nevertheless, according to Kaldor, in this view productivity is mainly to be explained by autonomous technical progress, but if this is true, how can we explain large differences in productivity growth across different countries at the same level of development in similar industries for such long periods? Hence, Kaldor argues that this relation can only have one significant direction of causality: from output to productivity growth.

2. Kaldor (1966) estimated Verdoorn's equation using data for the advanced countries over the period $1953 / 4$ to $1963 / 4$, and found a coefficient of 0.484 for the elasticity of manufacturing productivity to output, which is very similar to the value found by Verdoorn.

3. Kaldor (1975) suggested, alternatively, to regress employment, rather productivity, growth on output growth. As productivity growth is defined as the growth of output minus employment growth, there is an element of spurious correlation engendered by having output growth on both sides of the regression of the Verdoorn law. Nevertheless, regressing employment on output growth does not affect the value of the derived Verdoorn coefficient, which is the same whichever of these two specifications is estimated.

4. See McCombie (2002: 95-96) for a detailed discussion about simultaneous equation bias in both estimations.

5. Under the assumption of constant growth of the capital-output ratio for the long term, Verdoorn's law can be reduced to equation (1). However, it is not assumed here because shortterm variations in the growth of capital-output ratio can affect the value of Verdoorn's coefficient. 6. McCombie (2002) presents a detailed discussion about problems and advantages of this theoretical approach. 
7. There are many explanations for the existence of increasing returns to scale. Krugman (1991; 1998), for example, emphasises the effects of external economies of scale. According to him, the geographical clustering of activities can result in localisation economies. Clustering facilitates research and innovation in an industry, as well as the exchange of ideas and knowledge between firms. Furthermore, there is also the importance of Marshallian sources of external economies, such as market-size effects (backward and forward linkages), a thick local labour market, especially for specialised skills, and information spillovers.

8. Many studies, such as Angeriz et al. (2008, 2009), estimate the Verdoorn coefficient regressing total factor productivity growth on output growth. The advantage of this approach is that there is no need to assume that the capital-output ratio as exogenous to output growth to obtain the Verdoorn coefficient, such as assumed in this work. Nevertheless, to obtain the total factor productivity it is necessary to assume a value a priori for $a$, and $(1-a)$, which, following the neoclassical tradition, is usually obtained as the share of wages and profits in total income respectively.

9. Harris and Liu (1999), for example, use annual time-series data for GDP for a number of individual countries, but the data (and hence the estimates) are subject to the serious measurement errors discussed in the text. Most studies of the Verdoorn law use long-term average growth rates and very few use annual or quarterly data.

10. Hypothesis tests comparing these results were constructed based on the estimated coefficient and standard errors presented in Table 1. The t-statistic comparing capital goods and natural resources for equations (19) to (22) are, respectively, 0.91, 0.79, 0.82 and 0.79 , indicating that the null hypothesis that they present different Verdoorn coefficients cannot be rejected at the 10 percent level.

11. The t-statistic comparing high-tech and low-tech products for equations (19) to (22) are, respectively, $0.21,0.06,0.13$ and 0.07 .

12. The authors found higher increasing returns for all sub-sectors than for manufacturing, with the only exception of Textiles.

\section{References}

Angeriz, A., J.S.L. McCombie and M. Roberts, "New Estimates of Returns to Scale and Spatial Spillovers of EU Regional Manufacturing, 1986-2002”, International Regional Science Review, 31(1), 2008: 62-87. 
Angeriz, A., J.S.L. McCombie and M. Roberts, "Increasing Returns and the Growth of Industries in the EU Regions: Paradoxes and Conundrums”, Spatial Economic Analysis, 4(2), 2009: 127148.

Arrow, K.J. "Economic Welfare and the Allocation of Resources for Invention", In: National Bureau of Economic Research, Inc. (NBER), The Rate and Direction of Inventive Activity: Economic and Social Factors, Princeton University Press, 1962.

Barro, R.J. and J. Lee. “A New Data Set of Educational Attainment in the World, 1950-2010”, Journal of Development Economics, 2012. http://dx.doi.org/10.1016/j.jdeveco.2012.10.001

Barro, R.J. and X. Sala-I-Martin. "Technological Diffusion, Convergence, and Growth”, Jour nal of Economic Growth, 2(1), 1997: 1-27.

Cornwall, J. and W. Cornwall. "A Demand and Supply Analysis of Productivity Growth", Structural Change and Economic Dynamics, 13, 2002: 203-229.

Dutt, A.K. “Aggregate Demand, Aggregate Supply and Economic Growth”, International Review of Applied Economics, 20(3), 2006: 319-336.

Fagerberg, J. “Technology and International Differences in Growth Rates”, Journal of Economic Literature, 32(3), 1994: 1147-1175.

Fagerberg, J. and B. Verspagen. “Technology-gaps, Innovation-diffusion and Transformation: an Evolutionary Interpretation”, Research Policy, 31, 2002: 1291-1304.

Felipe, J. and J.S.L. McCombie. The Aggregate Production Function and the Measurement of Technical Change: “Not Even Wrong”, Camberley Surrey: Edward Elgar Publishing, 2013.

Harris, R.I.D and A. Liu, "Verdoorn's law and Increasing Returns to Scale: Country estimates based on the conitegration approach", Applied Economics Letters, 6, 1999: 29-33.

Hausmann, R., J. Hwang and D. Rodrik. "What You Export Matters", Journal of Economic Growth, 12(1), 2007: 1-25.

Kaldor, N. "Capital Accumulation and Economic Growth”. In: F.A. Lutz and D.C. Hague (eds) The Theory of Capital, London: Macmillan, 1961.

Kaldor, N. Causes of the Slow Rate of Economic Growth in the United Kingdom, Cambridge: Cambridge University Press, 1966.

Kaldor, N. "Economic Growth and the Verdoorn Law - A Comment on Mr. Rowthorn's Article", The Economic Journal, 85, 1975: 891-896. 
Kennedy, K. and A. Foley. "Industrial Development”. In: B. R. Dowling and J. Durkan (eds), Irish Economic Policy, Dublin: ESRI, 1978.

Krugman, P. R. Geography and Trade. Cambridge, Mass: MIT press, 1991.

Krugman, P.R. "What's New about the New Economic Geography?." Oxford Review of Economic Policy 14 (2) 1998: 7-17.

Lucas, R.E. "On the Mechanics of Economic Development", Journal of Monetary Economics, 22(1), 1988: 3-42.

Mankiw, N.G., D. Romer and D. Weil. "A Contribution to the Empirics of Economic Growth", Quarterly Journal of Economics, 107, 1992: 407-433.

McCombie, J.S.L. "Increasing Returns and the Manufacturing Industries: Some Empirical Issues", The Manchester School of Economics and Social Studies, 53(1), 1985: 55-76.

McCombie, J.S.L. "Increasing Returns and the Verdoorn Law from a Kaldorian Perspective", In: McCombie, J.S.L., M. Pugno and B. Soro, Productivity Growth and Economic Performance: Essays in Verdoorn's Law, New York: Palgrave Macmillan, 2002.

McCombie J.S.L. and de Ridder J.R. (1983) "Increasing Returns, Productivity, and Output Growth: the Case of the United States. Journal of Post Keynesian Economics 5(3) 1983: 373-387.

McCombie, J.S.L. and J.R. de Ridder "The Verdoorn Law Controversy": Some Empirical Evidence using U.S. State Data, Oxford Economic Papers, 36, 1984: 268-284.

McCombie, J.S.L. and M. Roberts. "Returns to Scale and Regional Growth: the Static-Dynamic Verdoorn Law Paradox Revisited”, Journal of Regional Science, 47(2), 2007: 179-208.

McCombie, J.S.L. and M.R.M. Spreafico. "Kaldor's 'Technical Progress Function' and the Verdoorn Law Revisited", Cambridge Journal of Economics, 40(6), 2016: 1117-1136.

Oi, W. Y. "Labor as a quasi-fixed factor", Journal of Political Economy, 70(6),1962: 538-555.

Palma, G. "Four Sources of 'De-industrialization and a New Concept of 'Dutch Disease"”, in: J.A. Ocampo (ed.) Beyond Reforms: Structural Reforms and Macroeconomic Vulnerability, Washington, DC: ECLAC, 2005.

Romer, P.M. "Increasing Returns and Long-run Growth”, Journal of Political Economy, 94(5), 1986: 1002-1037. 
Romer, P. M. "Endogenous technical change", Journal of Political Economy, 98(5), 1990: S71S102.

Rowthorn, R.E. “What Remains of Kaldor's Law?”, The Economic Journal, 85, 1975a: 10-19.

Rowthorn, R.E. “A Reply to Lord Kaldor's Comment”, The Economic Journal, 85, 1975b: 897901.

Salter, W.E.G. Productivity and Technological Change, Cambridge: Cambridge University Press, 1966.

Solow, R. “A Contribution to the Theory of Economic Growth”, Quarterly Journal of Economics, 70(1), 1956: 65-94.

Swan, T.W. "Economic Growth and Capital Accumulation", Economic Record, 32(2), 1956:33361.

UNIDO. Industrial Statistics Database 2-Digit Level ISIC Revision 3 (INDUSTAT2), Vienna: UNIDO, 2012.

UNIDO Industrial Development Report. Sustaining Employment Growth: The Role of Manufacturing and Structural Change, Vienna: UNIDO, 2013.

Verdoorn, P. J. (1949) Fattori che Regolano lo Sviluppo della Produttivita` del Lavoro, L'Industria, 1:3-10. English translation by A. P. Thirlwall, in: J.S.L. McCombie, M. Pugno and B. Soro, (2002) Productivity Growth and Economic Performance: Essays in Verdoorn's Law, Basingstoke: Palgrave Macmillan.

Young, A. (1928) "Increasing Returns and Economic Progress”, Economic Journal, 38(152):527542. 
Table 1 - Estimated Verdoorn coefficients (demand-side version), by industries and level of aggregation

\begin{tabular}{|c|c|c|c|c|}
\hline & No controls & $\begin{array}{l}\text { Controls: } \\
\text { Schooling }\end{array}$ & $\begin{array}{l}\text { Controls: } \\
\text { Tech Gap }\end{array}$ & $\begin{array}{l}\text { Controls: } \\
\text { Schooling, } \\
\text { Tech Gap }\end{array}$ \\
\hline Food & $\begin{array}{c}0.674 * * * \\
(0.136)\end{array}$ & $\begin{array}{c}0.695 * * * \\
(0.139)\end{array}$ & $\begin{array}{c}0.766^{* * * *} \\
(0.137)\end{array}$ & $\begin{array}{c}0.768 * * * \\
(0.134)\end{array}$ \\
\hline Textiles & $\begin{array}{l}0.334 * * \\
(0.140)\end{array}$ & $\begin{array}{c}0.369 * * \\
(0.145)\end{array}$ & $\begin{array}{c}0.369 * * * \\
(0.132)\end{array}$ & $\begin{array}{c}0.408 * * * \\
(0.128)\end{array}$ \\
\hline Paper & $\begin{array}{c}0.466 * * * \\
(0.062)\end{array}$ & $\begin{array}{c}0.471 * * * \\
(0.064)\end{array}$ & $\begin{array}{c}0.47 * * * \\
(0.081)\end{array}$ & $\begin{array}{c}0.474 * * * \\
(0.083)\end{array}$ \\
\hline Fuels & $\begin{array}{l}1.027 * * \\
(0.466)\end{array}$ & $\begin{array}{c}1.027 * * \\
(0.474)\end{array}$ & $\begin{array}{c}1.025^{* *} \\
(0.451)\end{array}$ & $\begin{array}{c}1.025 * * \\
(0.435)\end{array}$ \\
\hline Chemicals & $\begin{array}{c}0.687 * * * \\
(0.110)\end{array}$ & $\begin{array}{c}0.706^{* * *} \\
(0.095)\end{array}$ & $\begin{array}{c}0.696 * * * \\
(0.105)\end{array}$ & $\begin{array}{c}0.714 * * * \\
(0.103)\end{array}$ \\
\hline Non-metallic & $\begin{array}{c}0.579 * * * \\
(0.193)\end{array}$ & $\begin{array}{c}0.566^{* * *} \\
(0.212)\end{array}$ & $\begin{array}{c}0.555^{* * *} \\
(0.204)\end{array}$ & $\begin{array}{c}0.532 * * * \\
(0.202)\end{array}$ \\
\hline Metals & $\begin{array}{c}0.670 * * * \\
(0.136)\end{array}$ & $\begin{array}{c}0.696 * * * \\
(0.138)\end{array}$ & $\begin{array}{c}0.673 * * * \\
(0.120)\end{array}$ & $\begin{array}{c}0.686 * * * \\
(0.131)\end{array}$ \\
\hline Machinery & $\begin{array}{c}0.483 * * * \\
(0.132)\end{array}$ & $\begin{array}{c}0.492 * * * \\
(0.136)\end{array}$ & $\begin{array}{c}0.483 * * * \\
(0.136)\end{array}$ & $\begin{array}{c}0.491 * * * \\
(0.137)\end{array}$ \\
\hline Electrical & $\begin{array}{c}0.338 * * \\
(0.158)\end{array}$ & $\begin{array}{c}0.350 * * \\
(0.157)\end{array}$ & $\begin{array}{c}0.371 * * * \\
(0.136)\end{array}$ & $\begin{array}{c}0.366^{* * * *} \\
(0.138)\end{array}$ \\
\hline Transport & $\begin{array}{c}0.467 * * * \\
(0.12)\end{array}$ & $\begin{array}{c}0.474 * * * \\
(0.117)\end{array}$ & $\begin{array}{c}0.484 * * * \\
(0.124)\end{array}$ & $\begin{array}{c}0.489 * * * \\
(0.121)\end{array}$ \\
\hline Others & $\begin{array}{c}0.208 \\
(0.372)\end{array}$ & $\begin{array}{c}0.226 \\
(0.360)\end{array}$ & $\begin{array}{c}0.209 \\
(0.375)\end{array}$ & $\begin{array}{c}0.210 \\
(0.361)\end{array}$ \\
\hline Consumption Goods (CG) & $\begin{array}{l}-0.089 \\
(0.138)\end{array}$ & $\begin{array}{l}0.020 \\
(0.14)\end{array}$ & $\begin{array}{l}0.163 \\
(0.15)\end{array}$ & $\begin{array}{c}0.233 \\
(0.143)\end{array}$ \\
\hline Capital Goods (KG) & $\begin{array}{c}0.473 * * * \\
(0.149)\end{array}$ & $\begin{array}{c}0.49 * * * \\
(0.156)\end{array}$ & $\begin{array}{c}0.484 * * * \\
(0.176)\end{array}$ & $\begin{array}{c}0.496 * * * \\
(0.174)\end{array}$ \\
\hline Natural Resources (NR) & $\begin{array}{c}0.645 * * * \\
(0.116)\end{array}$ & $\begin{array}{c}0.642 * * * \\
(0.113)\end{array}$ & $\begin{array}{c}0.661 * * * \\
(0.126)\end{array}$ & $\begin{array}{c}0.662 * * * \\
(0.12)\end{array}$ \\
\hline Low-tech manuf. (LT) & $\begin{array}{c}0.462 * * \\
(0.209)\end{array}$ & $\begin{array}{c}0.478 * * \\
(0.197)\end{array}$ & $\begin{array}{c}0.466 * * \\
(0.227)\end{array}$ & $\begin{array}{c}0.482 * * \\
(0.208)\end{array}$ \\
\hline High-tech manuf. (HT) & $\begin{array}{c}0.519 * * * \\
(0.173)\end{array}$ & $\begin{array}{c}0.493 * * * \\
(0.149)\end{array}$ & $\begin{array}{c}0.503 * * * \\
(0.171)\end{array}$ & $\begin{array}{c}0.502^{* * *} \\
(0.168)\end{array}$ \\
\hline Manufacturing & $\begin{array}{c}0.527 * * * \\
(0.162)\end{array}$ & $\begin{array}{c}0.571 * * * \\
(0.159)\end{array}$ & $\begin{array}{c}0.548 * * * \\
(0.152)\end{array}$ & $\begin{array}{c}0.572 * * * \\
(0.153)\end{array}$ \\
\hline
\end{tabular}

Notes: Verdoorn coefficients estimated through System GMM for 70 countries and data ranging from 1963 to 2009 (unbalanced) based on seven-year average growth rates.

*: significant at $10 \%$ level; **: significant at $5 \%$ level; ***: significant at $1 \%$ level.

Standard errors in parentheses. 
Table 2 - Estimated Verdoorn coefficients (supply-side version), by industries and level of aggregation

\begin{tabular}{|c|c|c|c|c|}
\hline & No controls & $\begin{array}{l}\text { Controls: } \\
\text { Schooling }\end{array}$ & $\begin{array}{l}\text { Controls: } \\
\text { Tech Gap }\end{array}$ & $\begin{array}{l}\text { Controls: } \\
\text { Schooling, } \\
\text { Tech Gap }\end{array}$ \\
\hline \multirow[t]{2}{*}{ Food } & 0.115 & 0.072 & 0.136 & 0.115 \\
\hline & $(0.279)$ & $(0.287)$ & $(0.302)$ & $(0.302)$ \\
\hline \multirow[t]{2}{*}{ Textiles } & -0.157 & -0.152 & -0.085 & -0.042 \\
\hline & $(0.796)$ & $(0.741)$ & $(0.598)$ & $(0.591)$ \\
\hline \multirow[t]{2}{*}{ Paper } & 0.085 & 0.079 & 0.059 & 0.054 \\
\hline & $(0.278)$ & $(0.287)$ & $(0.286)$ & (0.294) \\
\hline \multirow[t]{2}{*}{ Fuels } & 5.381 & 8.853 & 3.479 & 3.988 \\
\hline & (5.053) & $(9.222)$ & (2.923) & (3.586) \\
\hline \multirow[t]{2}{*}{ Chemicals } & 0.022 & 0.062 & 0.170 & 0.174 \\
\hline & $(0.442)$ & $(0.474)$ & $(0.496)$ & $(0.495)$ \\
\hline \multirow[t]{2}{*}{ Non-metallic } & 0.337 & 0.293 & 0.224 & 0.278 \\
\hline & $(0.416)$ & $(0.55)$ & $(0.765)$ & $(0.736)$ \\
\hline \multirow[t]{2}{*}{ Metals } & -0.613 & -0.472 & -0.413 & -0.377 \\
\hline & $(0.759)$ & $(0.506)$ & $(0.507)$ & $(0.472)$ \\
\hline \multirow[t]{2}{*}{ Machinery } & 0.094 & 0.094 & 0.140 & 0.135 \\
\hline & $(0.348)$ & $(0.353)$ & $(0.326)$ & $(0.326)$ \\
\hline \multirow[t]{2}{*}{ Electrical } & -0.172 & -0.244 & -0.116 & -0.155 \\
\hline & $(0.513)$ & $(0.541)$ & $(0.356)$ & $(0.359)$ \\
\hline \multirow[t]{2}{*}{ Transport } & $-0.414^{*}$ & -0.385 & -0.309 & -0.307 \\
\hline & $(0.244)$ & $(0.244)$ & $(0.286)$ & $(0.284)$ \\
\hline \multirow[t]{2}{*}{ Others } & -0.633 & -0.664 & -0.635 & -0.744 \\
\hline & $(0.86)$ & $(0.884)$ & $(0.886)$ & $(0.94)$ \\
\hline \multirow[t]{2}{*}{ Consumption Goods (CG) } & -0.502 & -0.557 & -0.327 & -0.344 \\
\hline & $(0.471)$ & $(0.471)$ & $(0.467)$ & $(0.475)$ \\
\hline \multirow[t]{2}{*}{ Capital Goods (KG) } & -0.490 & -0.473 & -0.022 & -0.026 \\
\hline & $(0.604)$ & $(0.608)$ & $(0.442)$ & $(0.441)$ \\
\hline \multirow[t]{2}{*}{ Natural Resources (NR) } & 0.075 & 0.018 & -0.088 & -0.077 \\
\hline & $(0.449)$ & $(0.372)$ & $(0.425)$ & $(0.421)$ \\
\hline \multirow[t]{2}{*}{ Low-tech manuf. (LT) } & -0.272 & -0.251 & -0.437 & -0.419 \\
\hline & $(0.420)$ & $(0.336)$ & $(0.391)$ & $(0.388)$ \\
\hline \multirow[t]{2}{*}{ High-tech manuf. (HT) } & 0.045 & 0.042 & 0.145 & 0.147 \\
\hline & $(0.451)$ & $(0.446)$ & $(0.403)$ & $(0.398)$ \\
\hline \multirow[t]{2}{*}{ Manufacturing } & -0.356 & -0.352 & -0.326 & -0.289 \\
\hline & (1.035) & $(\mathbf{1 . 0 2})$ & $(1.015)$ & $(0.988)$ \\
\hline
\end{tabular}

Notes: Verdoorn coefficients estimated through System GMM for 70 countries and data ranging from 1963 to 2009 (unbalanced) based on seven-year average growth rates.

$*$ : significant at $10 \%$ level; **: significant at $5 \%$ level; ***: significant at $1 \%$ level.

Standard errors in parentheses. 